Article

\title{
Solar Access Assessment in Dense Urban Environments: The Effect of Intersections in an Urban Canyon
}

\author{
Elena Garcia-Nevado *, Anna Pages-Ramon and Helena Coch \\ Architecture \& Energy, School of Architecture of Barcelona, UPC, Av. Diagonal, 649, 7th floor, \\ 08028 Barcelona, Spain; anna.pages@upc.edu (A.P.-R.); helena.coch@upc.edu (H.C.) \\ * Correspondence: elena.garcia.nevado@upc.edu; Tel.: +34-93-4010868 \\ Academic Editor: Jukka Heinonen \\ Received: 8 July 2016; Accepted: 26 September 2016; Published: 6 October 2016
}

\begin{abstract}
The urban canyon model has been recurrently used as a basis for many solar access studies. However, its conception as endless structures disregards the effect of street intersections, despite being characteristic elements of urban fabrics. This paper aims to evaluate the impact of street discontinuities on solar access over building façades. The potential of crossings to increase the available radiation has been assessed through computer simulations in dense urban environments in a Mediterranean location. For the cases studied, results show that local effects of an intersection almost disappear beyond a specific distance for each aspect ratio, which can be helpful to determine the suitable level of detail for solar analyses at an urban fabric scale.
\end{abstract}

Keywords: urban morphology; solar access; direct radiation; street intersections; Mediterranean environment

\section{Introduction}

Urban morphology has been pointed out as one of the influencing factors with regard to the energy performance of cities from several points of view, including mobility [1], outdoor microclimate [2-4] and building energy behavior [5,6]. In the search for efficient urban forms, increasing physical density of settlements has been recurrently proposed as a suitable strategy because of its potential for reducing transport and land use [7]. However, in this compact city model, characteristic of Mediterranean cities, ensuring adequate solar access to buildings and public spaces may sometimes become a problematic issue $[8,9]$.

In order to understand the multiplicity of energy phenomena overlapping at urban contexts, it is helpful to describe urban form using geometric parameters which can be correlated to certain energy behaviors [10]. Due to the extreme heterogeneity of urban textures, this approach requires the development of simplified urban models, with the level of detail as a critical factor.

The urban canyon is a model widely used in energy studies. It is conceived as a geometric abstraction of the basic urban space composed of two parallel rows of buildings and the ground surface between them [11]. The key component of its attractiveness lies in its simplicity, since its geometric layout may be described by just two parameters: its axis orientation and its cross-sectional dimensions (width $\mathrm{W}$; height $\mathrm{H}$ ). This aspect ratio $(\mathrm{W} / \mathrm{H})$ is, in fact, an intuitive way of characterizing the occlusion of an urban fabric, but it represents only the obstructions located in a single direction (the vertical one). Canyon morphology has also been described quantifying the total amount of visible sky from a particular point, using other parameters such as sky view factor (SVF) $[12,13]$ or sky factor (SF) [14]. Although these descriptors are based on a multidirectional approach, they provide only a rough idea of the obstacles existing in the horizontal direction. 
The urban canyon model and the aforementioned geometrical parameters, commonly used for urban climatology purposes (e.g., wind patterns [15], urban heat island [16], and radiative exchanges [17]), have been also intensively applied to the study of solar access in buildings [18-23]. In spite of the undeniable usefulness of the canyon concept, modelizing streets as limitless rectangular troughs overlooks the 3D-complexity of urban tissues, essential for a better comprehension of urban energy exchanges [24-27]. In that sense, street intersections have so far received little attention in solar energy studies, unlike in wind flow investigations [28,29], despite being distinctive components of any fabric [30-32]. Depending on the design of crossings, the solar performance of urban fabrics may differ substantially, even though they are characterized by the same aspect ratio.

It can be stated that tissues with higher horizontal discontinuity also have a higher solar potential as a result of the reduction of the obstructions in the vicinity of intersections. However, no systematic assessment of the extent of this "crossing effect" has been conducted yet. Some questions arise in this regard. How far from the corner does the presence of a street junction affect? How meaningful is its contribution to solar radiation availability of urban tissues? Moreover, how significant is the deviation when solar analyses are conducted using simplified models that disregard intersections?

This paper addresses the issue of urban solar potential focusing on the role of street crossings in contrast to the widespread endless canyon approach. The specific aim of this research is to assess the impact of urban fabric discontinuities on solar access in dense Mediterranean environments, exploring the amount of direct radiation impinging over facades. This assessment is conducted on abstract models to draw energy-related conclusions exportable at a fabric scale.

\section{Method}

The method developed for the present study aims to assess the contribution of urban intersections to solar availability over façades in dense urban environment from a twofold perspective. On one hand, local effects on available radiation are analyzed depending on the distance to the corner. On the other hand, energy consequences of intersections are addressed at a street scale, focusing not only on changes in the amount of the radiation collected but also in its distribution. The influence of the urban fabric discontinuity on solar access is quantitatively evaluated through energy simulations as a basis for a subsequent qualitative discussion.

The methodological approach of this study, developed for Mediterranean locations, was built upon the comparison between urban models including and ignoring intersections in terms of solar energy received over façades. Models have been defined as abstract urban typologies in order to ensure the exportability of the analysis methodology. For this research, three geometric typologies were selected corresponding to the essential elements of design of any urban tissue (Figure 1): urban canyon (c), intersection (i), and street blocks (b). Accordingly, a three-step comparative analysis was carried out. In this paper, firstly, radiation results obtained for endless canyon models are presented as the baseline for comparisons with the rest of types. Secondly, the deviation from the canyon case introduced by intersection is evaluated. Finally, the influence of crossings on results for blocks is discussed.
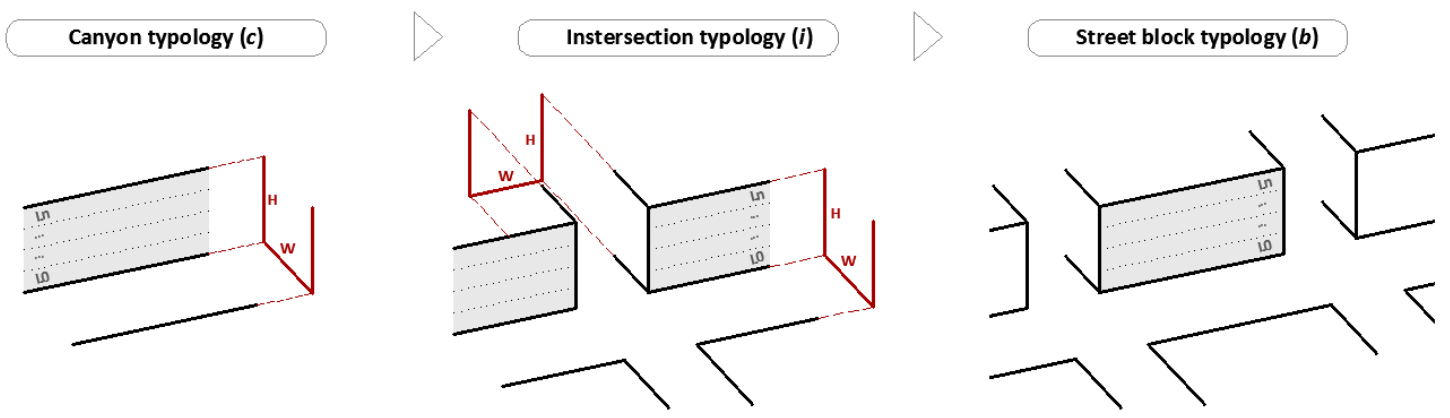

Figure 1. Urban typologies selected for this research. 
In this study, solar energy received over façades was assessed through a single parameter: direct solar radiation, the most significant component of sunlight for Mediterranean climates (e.g., in Barcelona city, direct contribution is between $62 \%$ and $72 \%$ of the monthly global solar radiation [33]).

Direct radiation was evaluated in terms of energy potential, i.e., considering a completely clear sky. Results were hence interpreted as the maximum direct radiation that a certain wall surface may receive under idealized conditions during a specific time period $\left(\mathrm{kWh} / \mathrm{m}^{2}\right)$. This approach provides radiation data strictly based on the geometry of the scene, suitable for the comparative purpose of the present study, though these values are an approximation of the actual ones.

Simulations were run on winter and summer solstice days in order to obtain a characteristic behavior under the extreme solar scenarios for each typological model (canyon, intersection, and block). Models were evaluated for several façade orientations, since radiation significantly differs depending on the direction the vertical surface is facing.

All calculations were conducted using Heliodon 2, a computer tool designed to visualise and calculate spatial and temporal distribution of solar radiation on urban and architectural models [34]. A general overview of the software is outlined below.

For a settled location, the software simulates the sun position as a latitude-and-time-dependent function. Once the geometry is modeled, the tool performs a sky visibility analysis from each point of the model considering the obstructions of the environment. These sky openings are correlated with the sun paths for each point to compute its sun exposure, using an isochronal projection [35].

In Heliodon 2, direct and diffuse components of sunlight were separately assessed. As regards direct radiation calculations, a cloudless sky was assumed during the whole year. For solar flux calculations, Heliodon takes into account the thickness of the atmosphere and therefore the latitude, the altitude, and the sun height [35]. Further details on the irradiation model and calculation assumptions can be found in [36].

Heliodon provides graphical and numerical information about the received radiation $\left(\mathrm{kWh} / \mathrm{m}^{2}\right)$ by integrating the solar flux in intervals defined by the user (year, season, month, hour, day). According to the user's preferences, radiation results can be obtained as punctual or cumulative values over surfaces, reporting average values if required.

Heliodon also allows the user to adjust spatial and time resolution for radiation calculation. For this research, time steps for calculation were fixed in $15 \mathrm{~s}$, and surfaces were discretized by a regular mesh with a $0.2 \mathrm{~m}$ width. These settings represent a good compromise between accuracy of results and computational costs given the scale of the model and the aim of the study.

Finally, it should be noticed that, as the main focus of this research is on the impact of the fabric morphology on solar access, energy consequences inextricably linked to its material properties or the presence of non-built elements have not been taken into consideration. Accordingly, reflections from neighboring surfaces were disregarded, and solar obstructions due to vegetation were not considered, thus obtaining radiation values in line with the maximum direct solar energy available.

\section{Description of the Case Study}

The "crossing effect" was assessed for a mid-latitude location corresponding to the city of Barcelona $\left(41^{\circ} \mathrm{N}\right)$, as an example of a dense Mediterranean urban environment. In Barcelona, like in most Mediterranean settlements, the traditional arrangement of built-up volumes highlights the street canyon as one of the main form givers of compact urban tissues [37] (Figure 2).

Study models for the canyon (c), intersection (i), and street block (b) typologies were built upon typical fabric dimensions of compact neighborhoods in Barcelona. A perpendicular intersection was chosen for the case study because it represents the most basic layout for a street junction, and it can be recurrently found in a wide number of city plans. An individualized analysis of typological models with an increasing degree of urban compactness was performed to assess the contribution of urban discontinuities to the solar potential. 

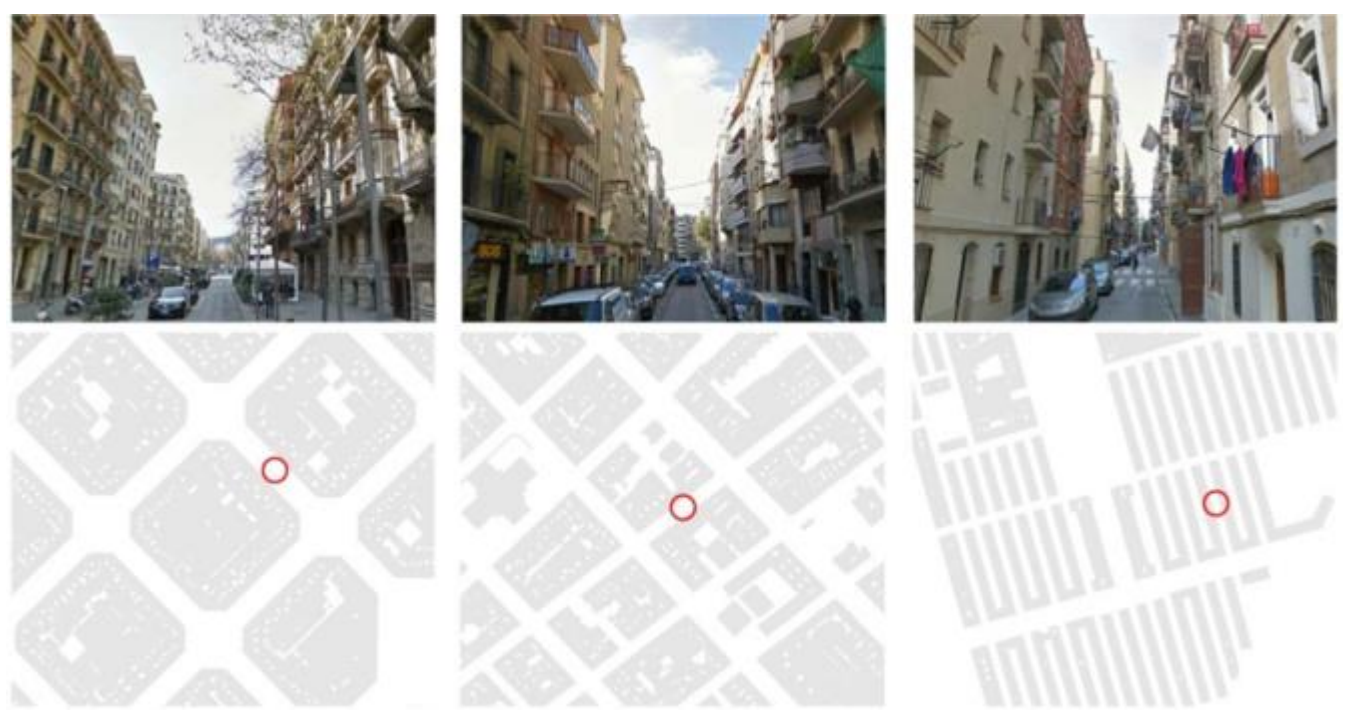

Figure 2. Examples of urban tissues and street canyon views in Barcelona. Source: [23].

Energy consequences in all models were addressed for façades facing eight orientations (N, NE, E, $\mathrm{SE}, \mathrm{S}, \mathrm{SW}, \mathrm{W}$, and $\mathrm{NW})$. Direct radiation $\left(\mathrm{kWh} / \mathrm{m}^{2}\right.$ per day) was computed over façades for the winter solstice (21 December) and the summer solstice (21 June), when sun elevation reached its minimum and maximum, respectively (Figure 3).

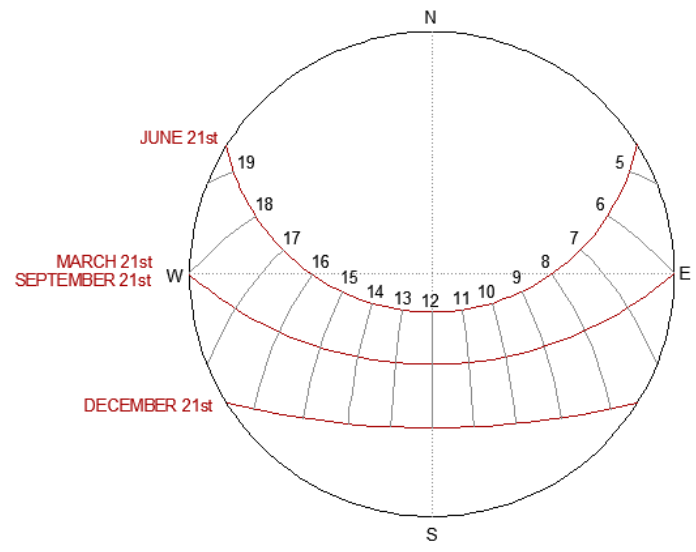

Figure 3. Stereographic projections of sun paths for a $41^{\circ} \mathrm{N}$ latitude.

The specific geometric layout of the three canyon models selected for this research (c-6; c-12; c-20) is provided in Figure 4. Canyon models are characterized by an aspect ratio $(\mathrm{W} / \mathrm{H})$ of 0,3 in the c-6 model, 0,6 in the c-12 model, and 1 in the c-20 model. Calculation points (L0-L5) have been defined along a vertical column over the façade at midpoint of each level.

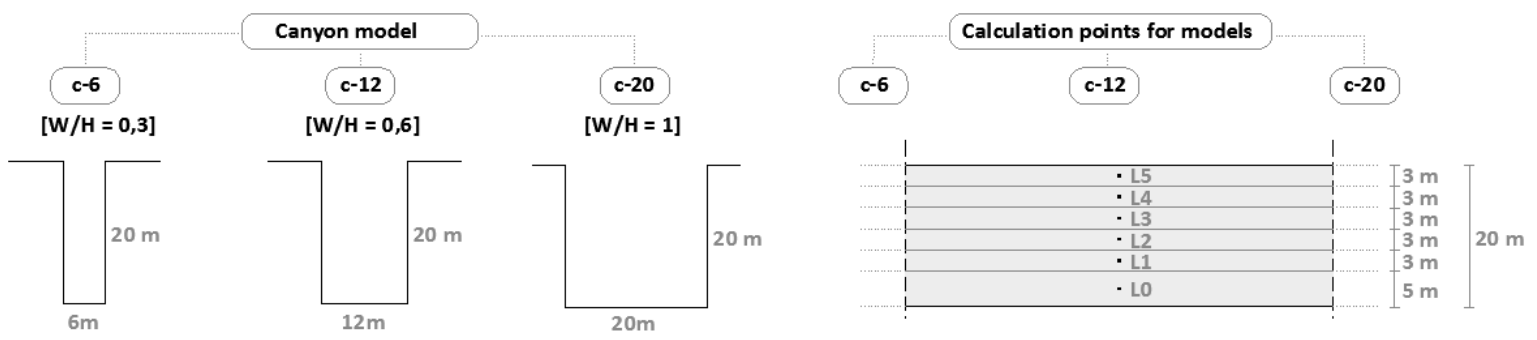

Figure 4. Geometrical layout of canyon models and distribution of calculation points. 
In order to assess the effects of street crossings on solar access, three intersection models (i-6; i-12; i-20) were defined based on the aforementioned canyon models (Figure 5). These intersection models were assumed here as semi-infinite 3D-structures, conceived as a perpendicular junction of two identical endless canyons. Calculation points were located on the nodes of the grid formed by rows at the midline of each floor level (L0-L5) and columns every $5 \mathrm{~m}$ starting from the corner edge (0-40 m).
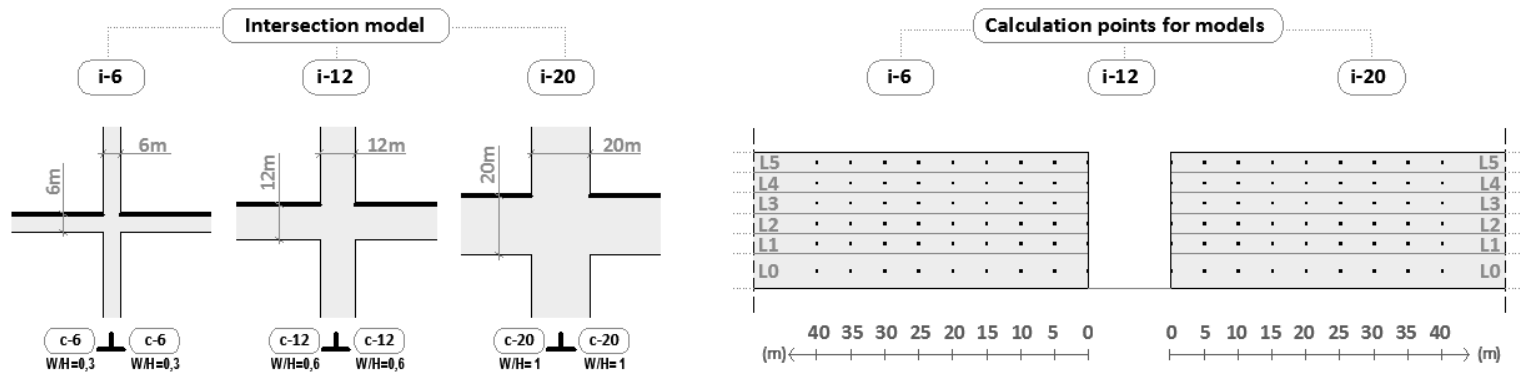

Figure 5. Geometrical layout of intersection models and distribution of calculation point.

Contrasting to the boundless nature of the canyon and intersection models, a block typology was created by fixing a specific longitudinal length as depicted in Figure 6. Three block models were defined with a street length of $10 \mathrm{~m}$ (b-10 model), $50 \mathrm{~m}$ (b-50 model), and $90 \mathrm{~m}$ (b-90 model). Radiation calculations were conducted on surfaces at each level. Blocks were considered as a part of urban tissues where crossings correspond to the i-6, i-12 and i-20 models.
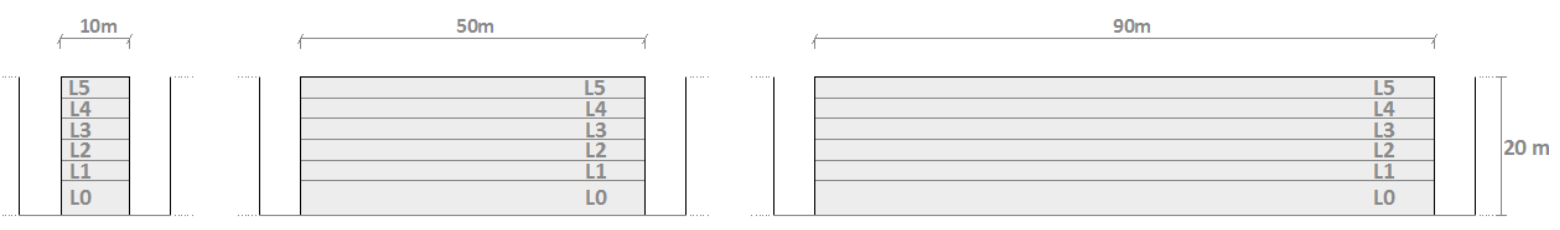

Figure 6. Elevation of the three street block models (b-10, b-50 and b-90).

\section{Results and Discussion}

\subsection{Urban Canyon Baseline}

The amount of direct solar radiation impinging on the selected points of the canyon models was calculated on solstice days for eight façade orientations. Notice that, in this study, orientations referred to the direction towards which the façade faced (Figure 7). For instance, the expression "south façade" would allude to the southern-facing wall.

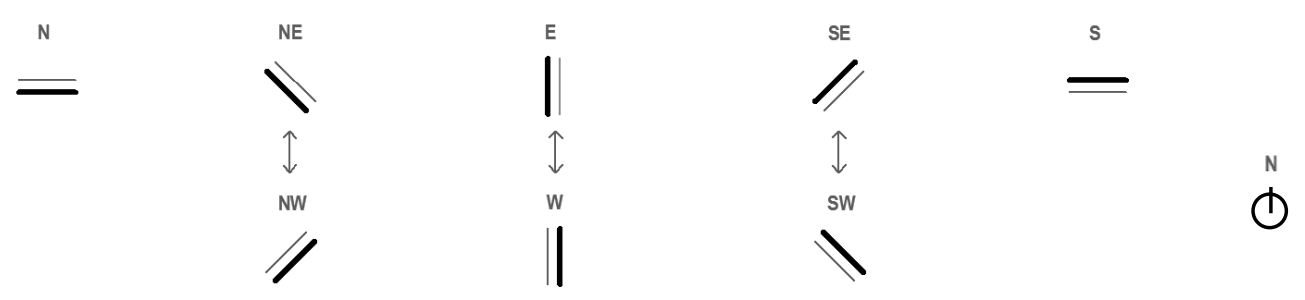

Figure 7. Façade nomenclature by orientation. Canyon plans with the studied façade in bold.

As representative values of the global performance of each façade, direct radiation values on levels L0 (min) and L5 (max) of the canyon models are presented in Table 1 for winter and in Table 2 for summer. 
Table 1. Radiation results over façades for canyons models on winter solstice ( $\mathrm{kWh} / \mathrm{m}^{2}$ per day).

\begin{tabular}{ccccccc}
\hline Canyon Model & Level & N & NE/NW & E/W & SE/SW & S \\
\hline \multirow{2}{*}{ c-6 $(\mathrm{W} / \mathrm{H}=0,3)$} & L0 & 0,0 & 0,0 & 0,0 & 0,0 & 0,0 \\
& L5 & 0,0 & 0,0 & 0,5 & 1,8 & 2,7 \\
c-12 $(\mathrm{W} / \mathrm{H}=0,6)$ & L0 & 0,0 & 0,0 & 0,1 & 0,0 & 0,0 \\
& L5 & 0,0 & 0,0 & 0,6 & 1,9 & 2,8 \\
$\mathrm{c}-20(\mathrm{~W} / \mathrm{H}=1)$ & L0 & 0,0 & 0,0 & 0,2 & 0,3 & 0,0 \\
& L5 & 0,0 & 0,0 & 0,6 & 2,0 & 2,8 \\
\hline
\end{tabular}

Table 2. Radiation results over façades for canyons models on summer solstice $\left(\mathrm{kWh} / \mathrm{m}^{2}\right.$ per day).

\begin{tabular}{lcccccc}
\hline Canyon Model & Level & N & NE/NW & E/W & SE/SW & S \\
\hline \multirow{2}{*}{ c-6 $(\mathrm{W} / \mathrm{H}=0,3)$} & L0 & 0,1 & 0,2 & 0,2 & 0,3 & 1,5 \\
& L5 & 0,4 & 1,6 & 2,6 & 2,4 & 1,5 \\
c-12 $(\mathrm{W} / \mathrm{H}=0,6)$ & L0 & 0,2 & 0,5 & 0,7 & 1,1 & 1,5 \\
& L5 & 0,4 & 1,7 & 2,7 & 2,4 & 1,5 \\
c-20 $(\mathrm{W} / \mathrm{H}=1)$ & L0 & 0,3 & 0,9 & 1,3 & 2,1 & 1,5 \\
& L5 & 0,4 & 1,7 & 2,7 & 2,4 & 1,5 \\
\hline
\end{tabular}

The maximum solar potential was detected on the south façade for the winter solstice $\left(2,8 \mathrm{kWh} / \mathrm{m}^{2}\right.$ per day) and on the east or west one for the summer case $\left(2,7 \mathrm{kWh} / \mathrm{m}^{2}\right.$ per day). In general, the narrower the street and the lower the sun elevation were, the more significant radiation differences could be found between the highest and lowest level.

On summer solstice, changes in radiation between extreme levels (L0 and L5) were more remarkable on those façades with an east or west component, whereas, in the winter case, stronger variations are linked to the south component as a result of lower sun positions.

\subsection{Deviation Introduced by Intersections}

The interruption of the archetypic endless canyon by an intersection allowed an increase in the amount of visible sky; the higher, the closer to the corner. Nevertheless, more visible sky did not always result in higher direct solar gains. This only happened when the unobstructed sky area matched the sun path.

Another noteworthy aspect to consider in the solar analysis of the crossing is the relative position between the street discontinuity and the point assessed. Uneven radiation effects were detected on both sides of an intersection for the same façade orientation, except for north and south façades (due to the sun path symmetry about the north-south axis).

This non-symmetrical condition is illustrated through the example of the NE façade belonging to the intersection i-20 model (Figure 8).

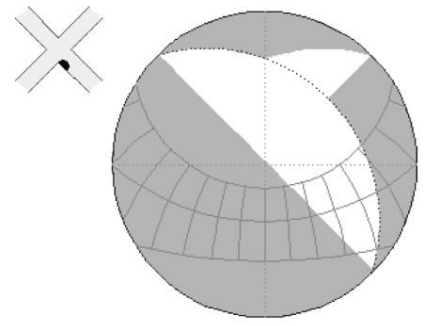

(a)

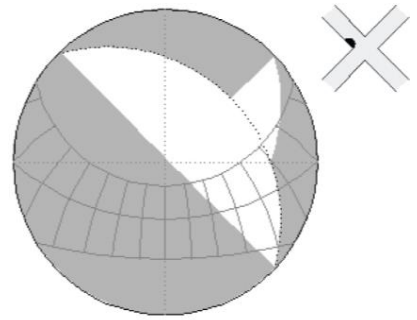

(b)

Figure 8. Sky obstruction diagrams and sun paths in stereographic projection from both corners of a $\mathrm{NE}$ façade. Observation points are located at the $\mathrm{L} 2$ level $(\mathrm{h}=9.5 \mathrm{~m})$ of the $\mathrm{i}-20$ intersection model. Shaded area corresponds to the part of sky masked by obstacles; unshaded area, to the visible sky fraction. Street discontinuity is located on the northern (a) or southern (b) position with respect to the corner. 
Diagrams in Figure 8 reflect how the presence of a crossing may or may not lead to an increase in sunlight hours depending on the side of intersection. In this case, only the façade fraction where the street interruption was placed further south experienced changes (Figure 8b). The visible sky area added by the intersection gap matches the sun path in Figure 8b, resulting in an increase in the received sunlight hours compared to the canyon case. In Figure 8a, on the contrary, any growth in the visible sky due to the crossing takes place over a sky area which is not crossed by the sun.

The energy-related consequences of this asymmetry are shown in Figure 9 for the NE orientation on the summer solstice day. At one side of the intersection (NE-corner S), the amount of direct radiation was modified by the street discontinuity up to a distance of $20 \mathrm{~m}$ from the corner, whereas at the other one it remained unchanged (NE-corner $\mathrm{N}$ ).

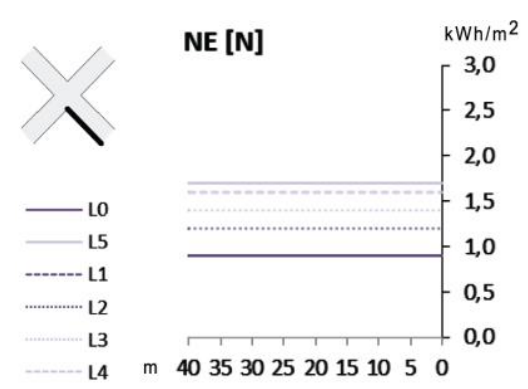

(a)

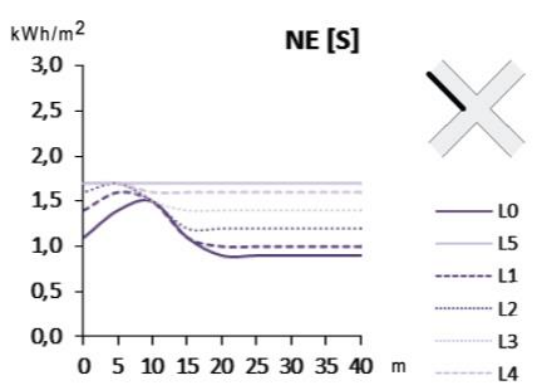

(b)

Figure 9. Direct solar radiation over the NE façade of the i-20 model $\left(\mathrm{kWh} / \mathrm{m}^{2}\right.$ per day) by distance from the corner $(\mathrm{m})$ for the summer solstice. Values when the street interruption is located on the north (a) or south (b) side of the corner edge.

Given the importance of the relative position of the corner edge, a specific nomenclature was developed and used for the comparative analysis of the crossing effect depending on the orientation below (Figure 10). Direct radiation patterns were plotted individually for each side of the intersection at a growing distance from the corner edge on both solstices (Figure 11). Radiation values on extreme levels (L0 and L5) have been graphically represented for the three intersection models.
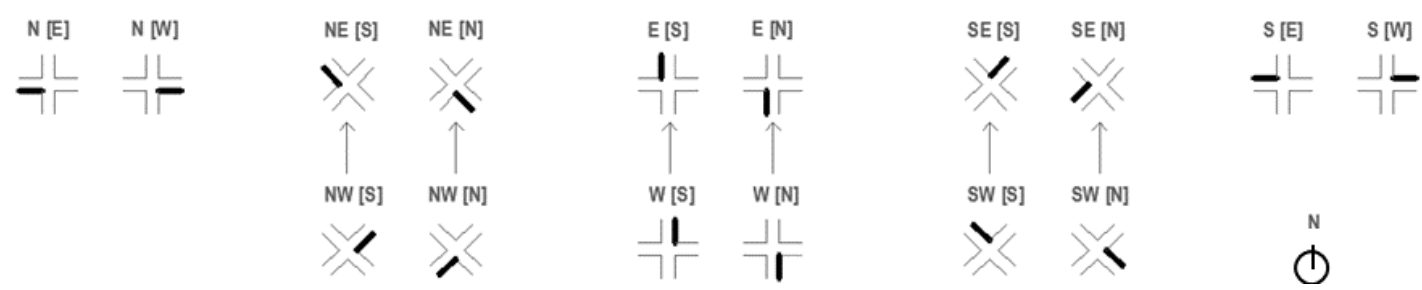

Figure 10. Intersection nomenclature by orientation. For each name, the first letter expresses the façade orientation; the letter in the square bracket indicates the relative position of the corner edge.

On the winter solstice, results show that the presence of a street junction leads to an increase in solar potential for all sunlit surfaces at this time of year. The most significant increment-in quantity and extent-occurred on SE/SW [S] surfaces, especially for wider models (up to $1,30 \mathrm{kWh} / \mathrm{m}^{2}$ per day for $\mathrm{i}-20)$. In the case of south façades, the crossing contribution can be also meaningful in value (e.g., $L 0$ might receive up to a third of the radiation on L5 at the corner in the i-20 model), though negligible effects $\left(<0,20 \mathrm{kWh} / \mathrm{m}^{2}\right.$ per day) were detected beyond $20 \mathrm{~m}$ for all models. Regarding east and west surfaces, the crossing introduced slight radiation increases in absolute terms (up to $0,20 \mathrm{kWh} / \mathrm{m}^{2}$ per day for i-20), while in relative terms they might be representative.

On the summer solstice, north and south facades remained unaffected by the crossing, whereas the rest of the orientations experienced significant energy variations. In the presence of a crossing, 
both sides on the intersection on $\mathrm{E} / \mathrm{W}$ façades experienced changes in radiation (an increase by up to $1,30 \mathrm{kWh} / \mathrm{m}^{2}$ per day). On the contrary, only one side was affected for NE/NW and SE/SW orientations, although these effects extended up to greater distances from the corner (up to $35 \mathrm{~m}$ ).

A maximum extent of the crossing was defined for each intersection model. Noticeable increases in radiation $\left(\geq 0,20 \mathrm{kWh} / \mathrm{m}^{2}\right.$ per day) were computed up to a maximum distance of 5,20 , and $25 \mathrm{~m}$ from the corner for the i-6, i-12 and i-20 models, respectively. These lengths correspond to a distance equivalent to $0,90 \mathrm{D}, 0,90 \mathrm{D}$, and $0,25 \mathrm{D}$, D being the diagonal of the cross section of the canyon $\left(\mathrm{D}=\sqrt{\mathrm{H}^{2}+\mathrm{W}^{2}}\right)$.

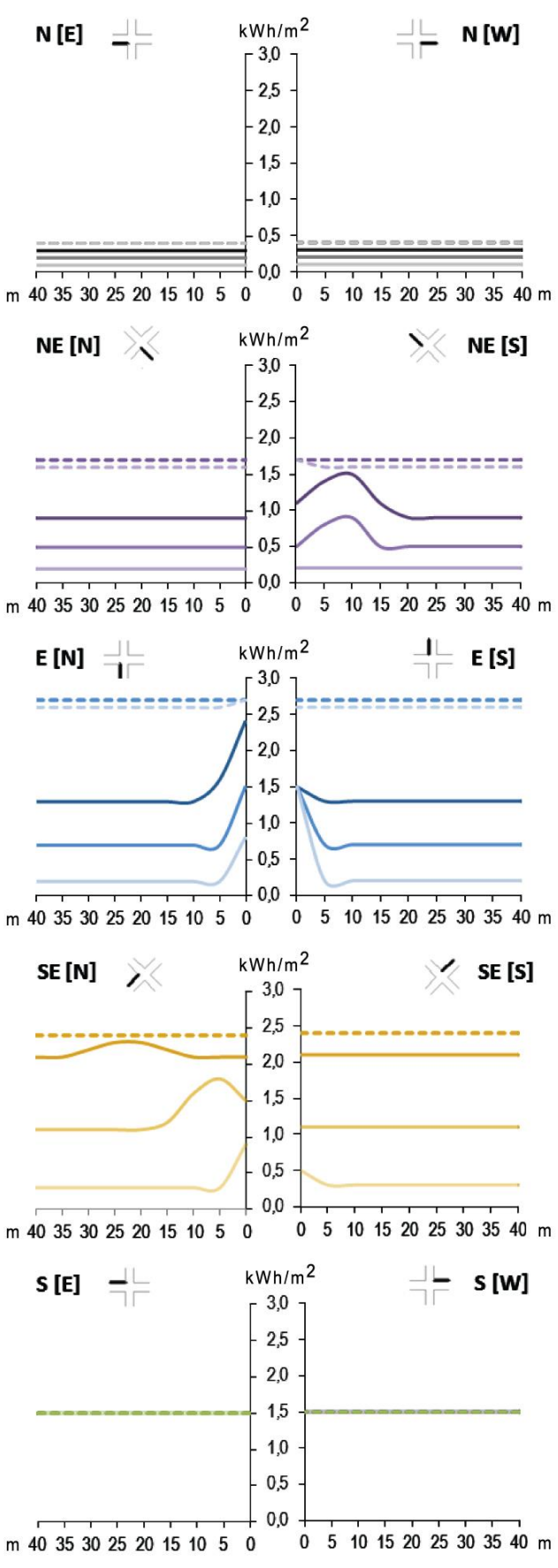

(a)
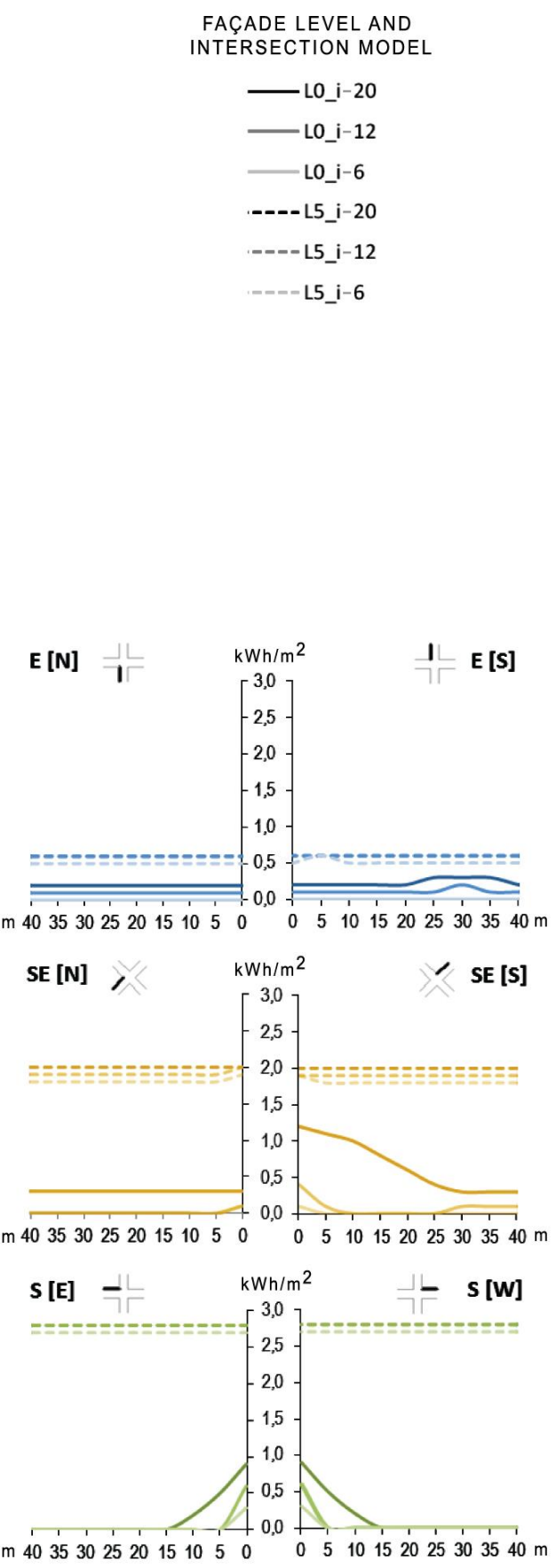

(b)

Figure 11. Direct solar radiation over façades $\left(\mathrm{kWh} / \mathrm{m}^{2}\right.$ per day) by distance from the corner $(\mathrm{m})$ on summer (a) and winter (b) solstices, on levels L0 and L5 for the three intersection models. 


\subsection{Street Blocks Type Models}

The deviation in relative terms between results for the theoretical endless canyon and blocks with a specified length is presented in Tables 3 and 4 for the summer and winter solstices, respectively.

Table 3. Deviation (\%) in direct radiation between canyon and block models on summer solstice.

\begin{tabular}{lcccccc}
\hline Block Model & Intersection & N & NE/NW & E/W & SE/SW & S \\
\hline \multirow{3}{*}{ b-10 (L=10 m) } & i-6 & $3 \%$ & $21 \%$ & $18 \%$ & $16 \%$ & $1 \%$ \\
& $\mathrm{i}-12$ & $3 \%$ & $29 \%$ & $12 \%$ & $10 \%$ & $0 \%$ \\
& $\mathrm{i}-20$ & $2 \%$ & $25 \%$ & $11 \%$ & $2 \%$ & $0 \%$ \\
b-50 (L-50 m) & $\mathrm{i}-6$ & $1 \%$ & $4 \%$ & $4 \%$ & $3 \%$ & $0 \%$ \\
& $\mathrm{i}-12$ & $2 \%$ & $6 \%$ & $3 \%$ & $3 \%$ & $0 \%$ \\
& $\mathrm{i}-20$ & $1 \%$ & $7 \%$ & $2 \%$ & $1 \%$ & $0 \%$ \\
b-90 (L- $=90 \mathrm{~m})$ & $\mathrm{i}-6$ & $1 \%$ & $3 \%$ & $2 \%$ & $2 \%$ & $0 \%$ \\
& $\mathrm{i}-12$ & $1 \%$ & $4 \%$ & $2 \%$ & $2 \%$ & $0 \%$ \\
& $\mathrm{i}-20$ & $1 \%$ & $4 \%$ & $1 \%$ & $1 \%$ & $0 \%$ \\
\hline
\end{tabular}

Table 4. Deviation (\%) in direct radiation between canyon and block models on winter solstice.

\begin{tabular}{lcccccc}
\hline Block Model & Intersection & N & NE/NW & E/W & SE/SW & S \\
\hline \multirow{3}{*}{ b-10 (L=10 m) } & i-6 & - & - & $11 \%$ & $28 \%$ & $41 \%$ \\
& i-12 & - & - & $10 \%$ & $48 \%$ & $67 \%$ \\
b-50 (L = 50 m) & i-20 & - & - & $7 \%$ & $44 \%$ & $65 \%$ \\
& i-6 & - & - & $4 \%$ & $6 \%$ & $8 \%$ \\
& i-12 & - & - & $6 \%$ & $12 \%$ & $6 \%$ \\
b-90 (L = 90 m) & i-20 & - & - & $6 \%$ & $13 \%$ & $16 \%$ \\
& i-6 & - & - & $3 \%$ & $3 \%$ & $5 \%$ \\
& i-12 & - & - & $4 \%$ & $7 \%$ & $8 \%$ \\
\hline
\end{tabular}

The disparity in radiation results between both cases is more remarkable on the winter solstice than on the summer one, due to the possibility of additional solar contributions due to crossings with lower sun elevations. As far as summer is concerned, for blocks larger than $50 \mathrm{~m}$ in length, the effect of discontinuities on radiation was barely noticeable $(<5 \%)$ for most orientations, whereas, in winter, the radiation increased by at least $5 \%$, even for the largest block analyzed here.

The smaller the block length was, the more significant contribution was computed, compared with the canyon model. Specifically, the radiation computed for the b-10 block could increase by up to $67 \%$ of that accounted for the canyon model.

To complete the study, the crossing effect regarding to the level was analyzed. Results indicate that the main increases in direct radiation occur in lower levels. As an example, radiation values accounted on each level for the i-12 model on both solstices are shown in Figure 12. In winter, the most remarkable effects were detected on street blocks facing south, on the b-10 model, and on lower levels. As far as summer is concerned, the most remarkable effects were also detected on the b-10 model, but for a different orientation: NE/NW.

BLOCK LENGTH
$=\mathrm{b}-90$
$=\mathrm{b}-50$
$=\mathrm{b}-10$
a Canyon c-12
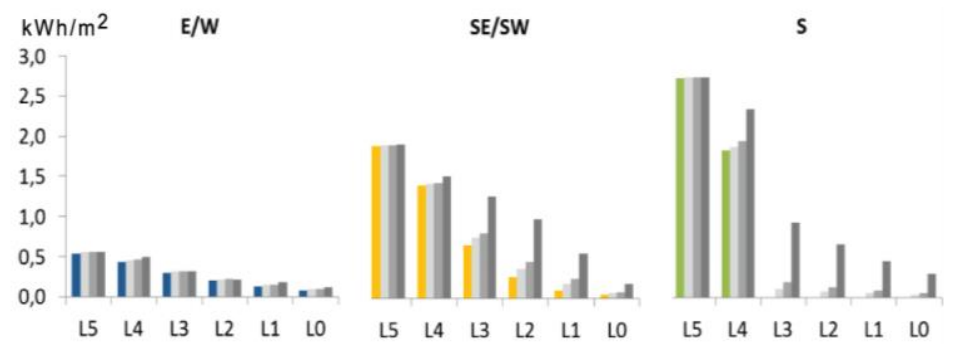

(a)

Figure 12. Cont. 


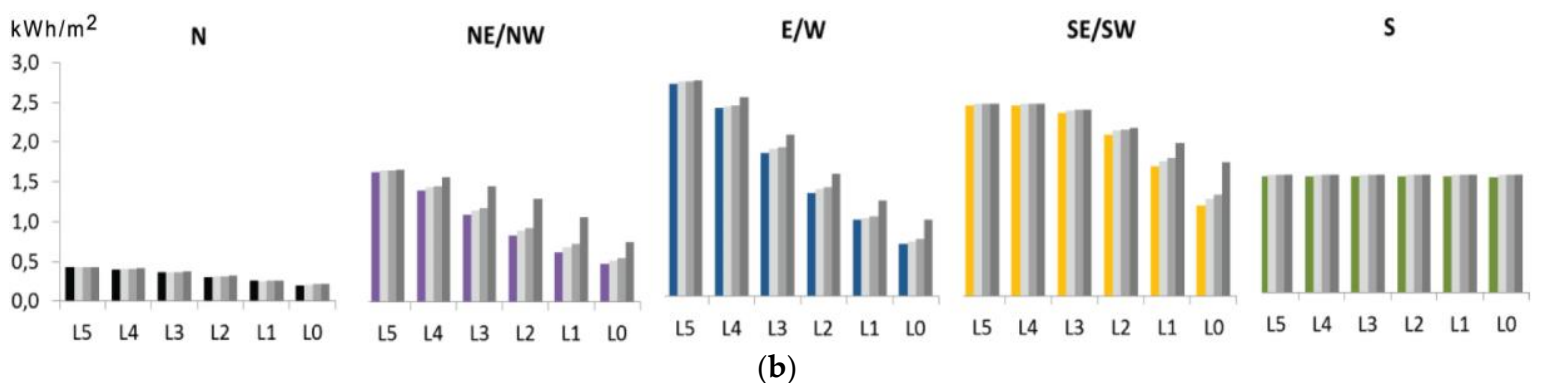

Figure 12. Comparison in terms of direct solar radiation by level $\left(\mathrm{kWh} / \mathrm{m}^{2}\right.$ per day) for the $\mathrm{i}-12 \mathrm{model}$ on winter (a) and summer (b) solstices among block and canyon models.

\section{Conclusions}

In this paper, the effects of street discontinuities on façade solar access are assessed for narrow canyons, typical of Mediterranean cities. The novelty of the present work lies in the fact that the role played by intersections on solar availability is discussed in order to explore the deviation from the canyon case, It has been assessed whether or not taking intersections into account can be significant in terms of received radiation depending on urban morphology and distance to the corner. This analysis was conducted by comparing the solar performance of the endless canyon to other typological models with a specific length, using the amount of direct solar radiation received over façades as an indicator.

At a local scale, results of this work show that the intensity and extent of the "crossing effect" depend not only on façade orientation, degree of obstruction, and time of year, but also on the relative position between intersection gap and the assessed point. As a consequence, uneven radiation patterns were detected on each side of the intersection.

The presence of a street junction leads to an increase in vertical solar potential that is more significant on those surfaces facing SE or SW for the winter solstice $\left(+1,3 \mathrm{kWh} / \mathrm{m}^{2}\right.$ per day) and those ones facing east or west for the summer solstice $\left(+1,1 \mathrm{kWh} / \mathrm{m}^{2}\right.$ per day). As a geometrical approximation for narrow environments, for those where the street width $\mathrm{W} \leq$ the height $\mathrm{H}$, (i.e., $\mathrm{W} / \mathrm{H} \leq 1)$, it can be said that the "crossing effect" is almost negligible $\left(<0,2 \mathrm{kWh} / \mathrm{m}^{2}\right.$ per day) beyond a maximum distance from the corner of $0,9 \cdot \mathrm{D}$, being $\mathrm{D}=\sqrt{\mathrm{H}^{2}+\mathrm{W}^{2}}$.

At a block scale, it has been found that solar energy analysis over façades disregarding intersections leads to deviations up to $67 \%, 16 \%$, and $9 \%$ for 10, 50 and 90-meter-length blocks, respectively, in winter. In the summer case, as a result of higher sun elevations, discrepancies in radiation results between canyon and block models are noteworthy only for the shortest block assessed. Hence, block results support the horizontal limit suggested by the local study of intersections here developed. The 50-meter length (or a 2.D length) can be considered a reference distance beyond which the effects of horizontal discontinuities begin to dilute in global results at a fabric scale.

For a Mediterranean climate with hot summers and mild winters, intersections have a positive global impact over urban surfaces facing south, since solar collection is increased in winter and not in summer. On the contrary, urban discontinuities have an adverse effect over east and west façades, as its contribution in winter is negligible, whereas the summer one can be significant. For other locations, further assessments should be carried out in order to incorporate its climatic considerations (e.g., latitude and the diffuse component) and characteristic street morphologies.

The contribution of this investigation is to provide indicative values about the distance from the corner beyond which the changes in solar radiation due to the crossing can be considered negligible and, accordingly, the endless canyon assumption sufficiently accurate. This information may provide general guidance for a more efficient discretization of urban surfaces in solar access analysis by differentiating areas requiring uneven degrees of calculation detail. Thus, this work contributes to a better understanding of the solar performance of cities, providing additional insights which can be useful in urban planning when designing new neighborhoods or refurbishing existing ones. 
Acknowledgments: This work has been supported by the Spanish Ministry of Economy under project code BIA2013-45597, and a FPU fellowship from the Spanish Ministry of Education granted to Elena Garcia Nevado.

Author Contributions: The three authors contributed equally to the present paper. Computer modelization and calculations were performed by Elena Garcia-Nevado. Anna Pages-Ramon and Elena Garcia-Nevado analyzed the data and wrote the paper. A general supervision was provided by Helena Coch. All authors have read and approved the final manuscript.

Conflicts of Interest: The authors declare no conflict of interest.

\section{References}

1. Steemers, K. Energy and the city: Density, buildings and transport. Energy Build. 2003, 35, 3-14. [CrossRef]

2. Golany, G.S. Urban design morphology and thermal performance. Atmos. Environ. 1996, 30, 455-465. [CrossRef]

3. Unger, J. Connection between urban heat island and sky view factor approximated by a software tool on a 3D urban database. Int. J. Environ. Pollut. 2009, 36, 59-80. [CrossRef]

4. Erell, E.; Pearlmutter, D.; Williamson, T. Urban Microclimate: Designing the Spaces between Buildings, 1st ed.; Earthscan: Washington, DC, USA, 2011.

5. Ratti, C.; Baker, N.; Steemers, K. Energy consumption and urban texture. Energy Build. 2005, 37, 762-776. [CrossRef]

6. Ewing, R. The Impact of Urban Form on U.S. Residential Energy Use. Hous. Policy Debate 2008, 19, 1-30. [CrossRef]

7. Jabareen, Y.R. Sustainable Urban Forms: Their Typologies, Models and Concepts. J. Plan. Educ. Res. 2006, 26, 38-52. [CrossRef]

8. Cheng, V.; Steemers, K.; Montavon, M.; Compagnon, R. Compact cities in a sustainable manner. In Proceedings of International Solar Cities Congress, Oxford, UK, 3-6 April 2006.

9. Curreli, A.; Roura, H.C. Solar access in the compact city: A study case in Barcelona. In Proceedings of 3rd International Conference on Passive and Low Energy Cooling for the Built Environment, Rhodes Island, Greece, 29 September-1 October 2010.

10. Adolphe, L. A simplified model of urban morphology: Application to an analysis of the environmental performance of cities. Environ. Plan. B 2001, 28, 183-200. [CrossRef]

11. Santamouris, M.; Asimakopoulos, D.N. Energy and Climate in the Urban Built Environment, 1st ed.; James \& James: London, UK, 2001.

12. Johnson, G.T.; Watson, I.D. The determination of View-Factors in Urban Canyons. J. Appl. Meteorol. Climatol. 1984, 23, 329-335. [CrossRef]

13. Matzarakis, A.; Matuschek, O. Estimation of Sky View Factor in Urban Environments. Available online: http://s3.amazonaws.com/academia.edu.documents/42812910/Estimation_of_Sky_View_ Factor_in_urban_e20160218-11663-rxsqtv.pdf?AWSAccessKeyId=AKIAJ56TQJRTWSMTNPEA\&Expires= 1474969817\&Signature=IE84tSktmCwTp5aUIvrbE8G95DI\%3D\&response-content-disposition=inline\% 3B\%20filename\%3DEstimation_of_Sky_View_Factor_in_urban_e.pdf (accessed on 8 July 2016).

14. Beckers, B. Geometrical Interpretation of Sky Light in Architecture Projects. Available online: http://www. heliodon.net/downloads/Beckers_2007_Helio_001_en.pdf (accessed on 8 July 2016).

15. Kastner-Klein, P.; Berkowicz, R.; Britter, R. The influence of street architecture on flow and dispersion in street canyons. Meteorol. Atmos. Phys. 2004, 87, 121-131. [CrossRef]

16. Oke, T.R. Canyon geometry and the nocturnal urban heat island: Comparison of scale model and field observations. J. Climatol. 1981, 1, 237-254. [CrossRef]

17. Harman, I.A.N.N. Radiative exchange in an urban street canyon. Boundary Layer Meteor. 2004, 110, $301-316$. [CrossRef]

18. Oke, T.R. Street design and urban canopy layer climate. Energy Build. 1988, 11, 103-113. [CrossRef]

19. Strømann-Andersen, J.; Sattrup, P. The urban canyon and building energy use: Urban density versus daylight and passive solar gains. Energy Build. 2011, 43, 2011-2020. [CrossRef]

20. Arnfield, A.J. Street design and urban canyon solar access. Energy Build. 1990, 14, 117-131. [CrossRef] 
21. Van Esch, M.M.E.; Looman, R.H.J.; de Bruin-Hordijk, G.J. The effects of urban and building design parameters on solar access to the urban canyon and the potential for direct passive solar heating strategies. Energy Build. 2012, 47, 189-200. [CrossRef]

22. Littlefair, P. Passive solar urban design: Ensuring the penetration of solar energy into the city. Renew. Sustain. Energy Rev. 1998, 2, 303-326. [CrossRef]

23. Garcia-Nevado, E.; Pages-Ramon, A.; Coch, H.; Beckers, B. Characterization of Solar Access in Mediterranean Cities: Oriented Sky Factor. In Proceedings of 31th Passive and Low Energy Architecture Conference, Bologna, Italy, 9-11 September 2015.

24. Montavon, M.; Compagnon, R.; Scartezzini, J.L. Comparison of the solar energy utilisation potential of different urban environments. In Proceedings of 21th Conference on Passive and Low Energy Architecture, Eindhoven, The Netherlands, 19-22 September 2004; pp. 1-6.

25. Robinson, D. Urban morphology and indicators of radiation availability. Sol. Energy 2006, 80, 1643-1648. [CrossRef]

26. Cheng, V.; Steemers, K.; Montavon, M.; Compagnon, R. Urban Form, Density and Solar Potential. In Proceedings of 23th Conference on Passive and Low Energy Architecture, Geneva, Switzerland, 6-8 September 2006.

27. Kanters, J.; Wall, M.; Dubois, M.C. Development of a Façade Assessment and Design Tool for Solar Energy (FASSADES). Buildings 2014, 4, 43-59. [CrossRef]

28. Shishegar, N. Street design and urban microclimate: Analyzing the effects of street geometry and orientation on airflowand solar access in urban canyons. J. Clean Energy Technol. 2013, 1, 52-56. [CrossRef]

29. Hosker, R.P. Flow around isolated structures and building clusters: A review. In Proceedings of American Society of Heating, Refrigerating and Air-Conditioning Engineers' Semiannual meeting, Honolulu, HI, USA, 23 June 1985.

30. Rubio-Bellido, C.; Pulido-Arcas, J.A.; Sánchez-Montañés, B.; Wong, N.H. A Simplified Simulation Model for Predicting Radiative Transfer in Long Street Canyons under High Solar Radiation Conditions. Energies 2015, 8, 13540-13558. [CrossRef]

31. Takebayashi, H.; Moriyama, M. Relationships between the properties of an urban street canyon and its radiant environment: Introduction of appropriate urban heat island mitigation technologies. Sol. Energy 2012, 86, 2255-2262. [CrossRef]

32. Garcia-Nevado, E.; Pages-Ramon, A.; Coch, H. Solar access assessment for Mediterranean urban environments: The extent of the "crossing effect". In Proceedings of 32th International Conference on Passive and Low Energy Architecture, Los Angeles, CA, USA, 11-13 July 2016; pp. 1-6.

33. Sancho, J.; Riesco, J.; Jiménez, C. Atlas de Radiación Solar en España utilizando datos del SAF de Clima de Eumetsat, 1st ed.Ministerio de Agricultura de España: Madrid, España, 2012.

34. Heliodon 2. Available online: http://heliodon.net/heliodon/index.html (accessed on 5 August 2016).

35. Beckers, B.; Rodriguez, D. Helping architects to design their personal daylight. WSEAS Trans. Environ. Dev. 2009, 5, 467-477.

36. Beckers, B.; Masset, L. Heliodon 2 Documentation. Available online: http://www.heliodon.net/downloads / Heliodon_Documentation_7203.pdf (accessed on 8 July 2016).

37. Krier, L. Urban Components. Archit. Des. 1984, 54, 40-69.

(C) 2016 by the authors; licensee MDPI, Basel, Switzerland. This article is an open access article distributed under the terms and conditions of the Creative Commons Attribution (CC-BY) license (http://creativecommons.org/licenses/by/4.0/). 